28. S. Lee, R. Carpenter. Creative thinking for 21 st century composing practices: Creativity pedagogies across disciplines. Across the Disciplines, № 12(4) (2015), http://wac.colostate.edu/atd/performing_arts/lee_carpenter2015.cfm (Accessed 11 August 2020).

29. R. Mudrochova. Teaching Writing in French at University and Students' Creativity as its Component. TOJET (August 2015), pp. 524-529.

30. Plan d'études romand. https://www.plandetudes.ch/home (Accessed 24 April 2020).

DOI 10.15826/B978-5-7996-3081-2.06

\title{
Implementation Features and Development Prospects in Distance Learning of Russian as a Foreign Language (RFL) at Pre-University Faculty
}

\author{
Alimova Maria', Gutorova Daria², Prokopova Ivanna \\ ${ }^{1}$ RUDN University, Moscow, Russia \\ ${ }^{2}$ Plekhanov Russian University of Economics, Moscow, Russia \\ ${ }^{3}$ Pushkin State Russian Language Institute, Moscow, Russia \\ Corresponding author: Alimova Maria, alimova.mv@yandex.ru
}

\begin{abstract}
The aim of this article is to describe the experience of e-learning of Russian as a Foreign Language (RFL) at the Pre-University Faculties based on the examples of three Russian educational organizations of higher education. The authors summarized the practical experience of Pre-University Faculties shift to e-learning in the period of the COVID-19 spread; the article also makes analysis of specific features characterizing this shift, describes the specifics of shifting the lessons into a digital mode and also examines the prospects of development of digital environment for the RFL Pre-University Faculty students. On the basis of the analysis, the authors describe the most common difficulties which faced both students and teachers. The results of this research show that distant learning became the only available instrument of the educational process functioning in the period of self-isolation when it was impossible to conduct face-to-face lessons. During the pandemic, the organization of the educational
\end{abstract}


process, including studying at the Pre-University Faculty, became the new starting point for the development, promotion and prospects of e-learning technologies in the field of education.

Keywords: e-learning, didgital environment, Russian as a Foreign Language (RFL), Skype, Zoom

\section{Introduction}

The widening of humanitarian contacts is one of the strategic priorities of the Russian Federation which is fixed in Concept of RF Foreign Policy.

Russia attracts $6 \%$ of all the foreign students in the world. It takes the $8^{\text {th }}$ place following the USA, Great Britain, Australia, China, Canada, Germany and France. In 2018 the share of international students increased by $5.7 \%$ and by $100 \%$ within the last decade. The majority of the international students in the RF are the citizens of CIS, Asia, Middle East and the North Africa [according to the website of RF Ministry of Science and Higher Education [Digital Resource].

By the year 2024 the number of international students in the educational institutions of higher education will reach 425000 people according to the estimates of the Federal Project "Export of Education" of the national project "Education".

The mechanism of attracting foreign citizens is based on a number of measures implemented by the educational institutions to provide the increase in the number of international students studying at the educational institutions of higher education, and also by the supporting measures which are to be provided by different bodies of public authorities and governmental agencies on the federal and regional levels.

An important contributing result of international students increase in the RF universities is the development of Russian educational organizations of higher education into Research and Educational Centers of highly-professional training for international students which are able to define the tendencies of global innovative development and will be able to face the new challenges of the XXI century.

Currently 310000 foreigners are accepted to all modes of studies including the main and additional education at about 450 educational institutions of the Russian Federation (pre-epidemic data). However, it has become clear that the pandemic can change dramatically the enrollment plans and the number of foreign students at Russian universities. 
Shift to the distant learning due to the epidemic of corona virus has become a true challenge for all of Russian education. In a report called "Cases of quick reactions of universities in the period of pandemics" the educational institution of National Research University Higher School of Economics defined this shift as 'force majeure circumstances' where the main reason for universities unreadiness to shift education into the digital environment were "dramatic changes in the conventional processes". [Cases of quick reaction of universities in the period of pandemic, 2020,27].

In another report by National Research University Higher School of Economics 'Lessons of 'stress-tests'. Universities under the conditions of pandemic and after it' it was mentioned that "foreign students turned out to be the most vulnerable group of students whose chances to come back to "normal teaching and learning process" by September 2020 are not evident". [The lessons of "stress-test". Universities under the conditions of pandemic and after it, 2020, 27].

Really and truly, the Pre-University Faculties, which get foreign citizens ready to studying at Russian universities, had to face a real challenge. Not every Pre-University Faculty was completely ready for such a dramatic shift to e-learning. It is connected with various factors, including lack of crucial digital infrastructure in a number of universities, which would make it possible to shift the process of teaching and studying into the distant mode, and lack of efficiency of the digital educational environment. By the digital educational environment, we mean a system of informative, technological, methodological resources and tools, which were able to provide a remote teaching and studying process.

Computerization of the educational sphere, integration of modern information and communication technologies in the process of foreign languages studying ensures the ability to provide a completely new level and is an integral part of progress.

However, e-learning, which was being so much written about in the previous decades, has just undergone battle testing to prove that it is ready for the global changes in all the parts of the educational chain. Skills and competences which the developers of modern teaching mediums require from teachers, students and educational managers and also the ways to build-up communication among all the participants of the educational process got into the "turbulence zone" in the process of shifting to the e-learning. And although everybody understood that "information and communicative technologies 
in the sphere of education is a kind of infrastructure connected with the perception, which changes the very dialogue and understanding of participants of teaching/learning process and thus the forms of perception, organization and the process of education" [Bogomolov, 2008, 22], there was not provided a systematized practice of e-learning realization at the Pre-University Faculties.

Let us point out that academics pay attention to a number of terms which describe the process of distance learning and the fact that they are confusable (this refers to the terms "e-learning", "distant education" and "distance technologies of education"). Detailed description of the topic in question can be found in the work of A. Bogomolov "Virtual environment in teaching and learning of Russian as a foreign language: linguistic and cultural aspects" [2008]. In our article, we are using the term "e-learning" in the meaning offered by A. Bogomolov. We are going to define the term as "intentional synchronous or non-synchronous process of interaction among the participants of the teaching and studying process provided with the help of distant training devices within the help of a specialized educational environment based on implementing information and telecommunication technologies [Bogomolov, 2008, 53]. The main advantage of e-learning is an opportunity to study any time and in any place (Anywhere Anytime Learning). Various educational platforms are being created for e-learning in the digital environment. Their aim is to optimize and facilitate the work of students and teachers. For the time being, it is possible to talk about a whole cluster of distant educational technologies. [Prokopova, 2019, 22]. In the point 1 of article number 16 of the Federal Law of 29.12.2012 № 273-Ф3 (edited on 31.07.2020) "Federal Law of the Russian Federation on Education" (Edited and amended, went into effect on 01.08.2020). 'Distant educational technologies' are understood as "educational technologies which use IT and telecommunication networks to provide mediated (distant) interaction of students and teachers" [Laws, codes and regulations of the Russian Federation [Electronic resource].

It was common before the spread of corona virus infection to provide primarily classroom learning for students coming to the Russian Federation who had intensive training in Russian and general subjects to continue their studies at Russian universities. The programs, which provided this kind of training, were regulated by a number of federal laws and orders. Among these are:

1. Federal law of Russian Federation of $29^{\text {th }}$ December 2012 № 273-Ф3 "The Law of the Russian Federation on Education". 
2. Order of Ministry of Education and Science of the 28th July 2014 № 844 "On the rules of selection of foreign citizens and people without citizenship to study within the education quote established by the Government of Russian Federation for the education of foreign citizens and people without citizenship".

3. Order of Ministry of Education and Science of the RF of the $5^{\text {th }}$ April 2017 № 301 “On arrangement procedures and educational activities conduct in the educational programs of higher education - Bachelor program, Specialist program, Magistrate program".

4. Order of Ministry of Education and Science of the RF of the $3^{\text {rd }}$ October 2014 № 1304 “On requirements to master the additional programs in General subjects providing professional training to prepare foreign citizens and people without citizenship to study majors in Russian language".

5. Order of the Ministry of Education and Science of the RF of the 1 April 2014 г. № 255 “On requirements to the levels of linguistic proficiency for Russian as a foreign language and their criteria".

6. Order of the Ministry of Education and Science of the RF of the 14 October 2015 № 1147 “On the rules of acceptance to the educational programs of the higher education Bachelor program, Specialist program, Magistrate program".

It posed a real challenge to implement e-learning at the Pre-University Faculties since it is also controlled by regulatory documents. For instance, point 3 of article number 16 of 29.12.2012 № 273-FZ (edited on 31.07.2020) "Federal Law of the Russian Federation on Education" (edited and amended, went into effect from 01.08.2020) says: "When implementing educational programs using only e-learning, distance educational technologies in organizations providing learning activities, it is necessary to provide conditions for electronic information and educational environment, including electronic informational resources, electronic educational resources, a combination of IT and telecommunication technologies, corresponding software tools and educational programs which insure that the students will be able to master the program to the full extend regardless the whereabouts of the student". [Laws, codes and regulations of the Russian Federation [Electronic resource]].

It is clear that to prepare distance learning programs, the universities must allocate considerable means, which they do not always have at their disposal. Moreover, it is clear that the undeniable advantages of the traditional mode of learning are crucial at the Pre-University Faculties. Thus, there was not an opportunity to go through an e-leaning course of the Pre-University 
Faculty, take an exam and get a certificate online. However, in March 2020 all the educational institutions of Moscow had to shift to e-leaning and Pre-University Faculty was not an exception.

Addressing the research questions: How did the Russian educational institutions of higher education face the epidemiological challenges of 2020 ? How was this shift organized for Russian and foreign students? Which difficulties did teachers and students face?

\section{Sampling material}

In the course of our studies, we looked into the experience of three educational institutions of higher education. They are:

- Plekhanov Russian Economy University

- Pushkin State Russian Language Institute

- Russian Peoples' Friendship University

We took the e-learning experience of these three universities from March until June of 2020 as study material for our research.

\section{Methodology and Methodic of this research}

As a part of our research we used such general-logic, academic, empirical and special methods as analysis, synthesis, generalization, description and questionnaire survey.

\section{Research description}

4.1. Experience of Pre-University Faculty operation under pandemic conditions

How did the process of teaching at Plekhanov Russian Economy University, Pushkin State Russian Language Institute and Russian Peoples' Friendship University change during the pandemic?

The universities complied with all the recommendations provided by the orders of the Russian Ministry of Education and Science and Moscow Mayor's Decrees on prevention of the spread of the corona infection. There were taken all the measures to provide safety and health protection of all the students and teachers.

At the first stage from 16 March 2020 Russian Peoples' Friendship University introduced flexible attendance which meant that students could choose whether to come to class or choose e-learning. Flexible attendance is an opportunity for students not to come to classroom on a compulsory 
basis, but instead study with the help of distant studying technologies. Subsequently, due to the worsening of the epidemiological situation in Moscow, classroom learning was stopped and every department/university/academy was ordered to provide the e-study. Adapted curricula with the lists of subjects of studies were posted on the platform Telecommunication Studying and Information System (TSIS).

Teachers were advised to use such programs as Zoom, Microsoft Teams or Skype to hold workshops. Microsoft Teams application was widely recognized among the teachers and students as both had corporate access to the full version of this product and also because the program provided a wide variety of online services (whiteboard, online-applications (translates), text modeling, group and individual chats with students, checking homework without downloading files, recording and its auto save in the cloud storage, etc.).

All the classroom timetables were shifted to e-learning. Students were provided with computers, teachers went through special training, special instructions were created to work with the programs in question. The University set up a "hotline" to answer the questions on the organization of the learning process using e-learning and distant learning technologies. Interactive lessons with videoconferencing, testing, virtual classes and cloud storages helped provide the interaction among the teachers and students, comfortable material delivery and provided various opportunities to test students' knowledge.

It is clear that teachers and students of the Pre-University Faculty had to adapt the format and the delivery of new material and thus its digestion. It was impossible to stop using student books and workbooks altogether, however many manuals and learning guides of the RPFU were digitalized. Based on several months performance, it is possible to come to the conclusion, that e-learning requires changes in material delivery: e-learning requires more visual materials and while having a group e-lesson it takes longer to control material understanding and digestion. This is especially relevant to foreign language learning at the initial stage. We mean not only the tests and exercises, but also the very process of new material understanding and its further digestion.

It is worth mentioning the process of attendance and lessons control. The department administration worked out electronic individual and group education plans, research grade books, online attendance records.

All the final exams and credits were duly held using e-learning and distance educational technologies 
The Pre-University Faculty of Plekhanov Russian University of Economics shifted to e-leaning on the $17^{\text {th }}$ of March 2020 and the process of learning was carried out in a combined mode: synchronous e-learning combined with asynchronous.

Synchronous e-learning was carried out with the help of videoconferencing using cloud services of synchronous learning such has Zoom, Skype. Asynchronous online learning was carried out without using LMS a platform in the mode characteristic to offline leaning: students did their homework in their workbooks, some homework was sent to e-mail or its recordings were sent to WhatsApp or other kinds of messengers. In the process of online learning students were offered both traditional kinds of work (reading/retelling of texts, doing written works, listening, doing tests, etc.) and also other forms of studying which are characteristic largely of distant learning (team work on the whiteboards, making of mental maps, etc.)

To carry out the final Russian language exam, the staff of the Russian language and Culture of speech chair prepared materials suitable for the online delivery mode. As the target of the Pre-University Faculty for foreign citizens and citizens without citizenship is to reach the lever TORFL- 1 (Test of Russia as a Foreign Language), as it allows them study successfully the main educational programs in Russian language at the universities of the Russia Federation, the materials of the final exam met the requirements of the exam level. A final test made it possible to test the established skills and proficiency of the students based on 5 subtests in 'Lexis. Grammar', 'Listening, 'Reading', 'Writing', 'Speaking. All the subtests but 'Speaking (conducted via Skype) were provided in Google Forms. "Speaking” part was carried out via Skype.

The Pre-University Faculty of Pushkin State Russian Language Institute prepares foreign citizens for bachelor, magistrate, specialist and post-graduate studies at Russian universities. Foreigners study at the department by the assignment of the Ministry of Science and Higher Education of the Russian Federation or on the contract basis.

From 17 March 2020 due to the prophylactic measures against of the new corona virus infection Pushkin Institute shifted to e-learning. The timetable remained intact and all the lessons were conducted via an online mode. To conduct contact inline lessons, teachers were advised to use such programs as Zoom and Skype. The university provided access to the corporate version of Zoom which made it possible to create a comfortable process of online teaching and learning for teachers and students. To conduct lessons in the IT educational 
environment all the students were registered for online courses of Russian as a foreign language and major subjects in Russian language on the basis of LMS Canvas on the portal "Education on Russian" (http://pushkininstitute.ru/). For teaching staff, there were organized webinars and they were provided with instructions of working with the LMS Canvas system. Online curators of the courses provided timely problem-solving of all the technical challenges.

The IT educational environment based on LMS Canvas on the portal "Education in Russia" provides teachers with an opportunity to create their own interactive courses, which meets the requirements of the curriculum and provides a personalized approach. The number of students in the group remained the same (up to 15 people).

At the end of the day, teachers sent reports where they mentioned the time of the lesson, topic, the system used and homework.

All the forms of the midpoint assessment were also organized on the basis of LMS Canvas.

\subsection{Questionnaires}

Distant learning and teaching mode also brought to light some challenges in the process of teaching at the Pre-University Faculty which every teacher faced to some extent. Let us list some of them:

1. Technical challenges: unstable Internet connection, some students did not have computers, laptops, tablet PCs or Russian keyboard.

2. Organizational and methodical challenges: inability to substitute class lessons by applications provided, adapting the curriculum to an IT environment; difficulties in keeping student attention working online; discipline problems (attendance of online lessons dropped in comparison with traditional class lessons; teachers had difficulties in controlling, disciplining and motivating students); difficulties in learning control and assessment.

3. Personnel challenges: some teachers were not ready to work on the online mode.

However, not only teachers, but also students experienced difficulties. The authors of this research carried out a poll in June 2020 among the students of the Pre-University Faculty in order to get feedback from students and their own estimations of their studies from March until June.

55 students took part in the first poll "Difficulties during the quarantine" (Diagram 1, Table 1).

The second poll "Difficulties in the process of online learning" (Diagram 2, Table 2) was carried out to collect information about the kinds 
of difficulties students experienced while studying distantly. 55 students took part in this poll.

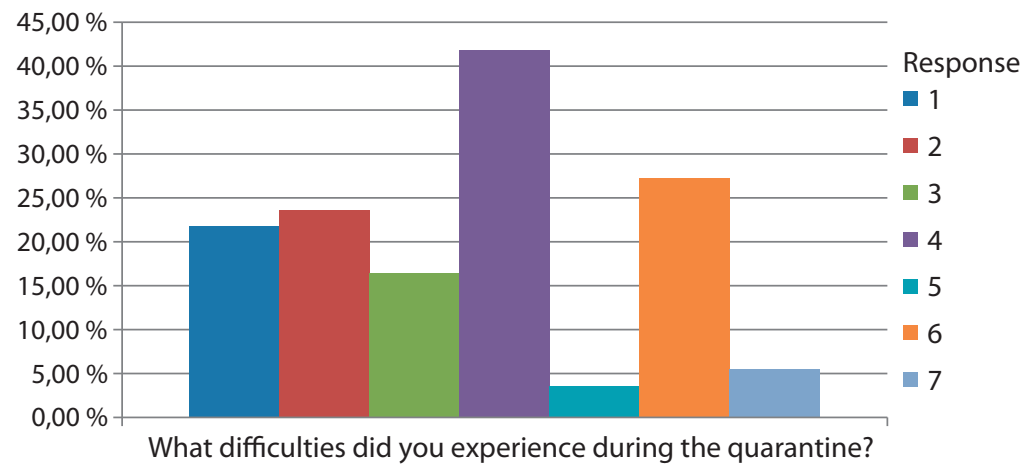

Diagram 1. Difficulties during the period of quarantine

First questionnaire results

\begin{tabular}{|c|c|c|c|}
\hline № Response & Answer options & $\begin{array}{l}\text { Number of } \\
\text { respondents } \\
\text { (persons) }\end{array}$ & Percentage (\%) \\
\hline Response 1 & $\begin{array}{l}\text { I did not know how } \\
\text { to book an electronic } \\
\text { pass; what to do if I get ill; } \\
\text { what I can and cannot do } \\
\text { during the quarantine }\end{array}$ & 12 & 21,8 \\
\hline Response 2 & $\begin{array}{l}\text { I was concerned with } \\
\text { the corona virus situation } \\
\text { in Russia/my country/ } \\
\text { the world; I experienced } \\
\text { the lack of up-to-date } \\
\text { information on the current } \\
\text { situation and the length } \\
\text { of the quarantine. }\end{array}$ & 13 & 23,6 \\
\hline Response 3 & I felt lonely and sad. & 9 & 16,4 \\
\hline Response 4 & E-learning was hard for me. & 23 & 41,8 \\
\hline Response 5 & $\begin{array}{l}\text { I have health problems } \\
\text { and did not know how } \\
\text { to solve them }\end{array}$ & 2 & 3,6 \\
\hline
\end{tabular}


End of Table 1

\begin{tabular}{l|l|c|c}
\hline № Response & \multicolumn{1}{|c|}{ Answer options } & $\begin{array}{c}\text { Number of } \\
\text { respondents } \\
\text { (persons) }\end{array}$ & Percentage (\%) \\
\hline Response 6 & $\begin{array}{l}\text { I did not experience any } \\
\text { difficulties within this } \\
\text { period }\end{array}$ & 15 & 27,3 \\
\hline Response 7 & $\begin{array}{l}\text { Others (write your own } \\
\text { answer) }\end{array}$ & 3 & $\begin{array}{l}\text { - "It is fine, even } \\
\text { convenient. I think } \\
\text { that the teachers } \\
\text { effectively adapted } \\
\text { to the situation and } \\
\text { helped me in the pro- } \\
\text { cess of studying”. } \\
\text { "It was difficult } \\
\text { to buy food". } \\
\text { "It is boring to stay } \\
\text { at home all the time". }\end{array}$ \\
\hline
\end{tabular}

The results of the second questionnaire

\begin{tabular}{l|l|c|c}
\hline № Response & \multicolumn{1}{|c|}{ Response option } & $\begin{array}{c}\text { Number } \\
\text { of respondents } \\
\text { (people.) }\end{array}$ & $\begin{array}{c}\text { Percentage } \\
\text { (\%) }\end{array}$ \\
\hline Response 1 & Internet problems & 19 & $\mathbf{3 2 , 8}$ \\
\hline Response 2 & $\begin{array}{l}\text { I did not have a laptop } \\
\text { computer/tablet PC/personal } \\
\text { computer, only my mobile }\end{array}$ & 14 & 24,1 \\
\hline Response 3 & $\begin{array}{l}\text { I did not have a Russian } \\
\text { keyboard and could not type } \\
\text { in Russian }\end{array}$ & 4 & 6,9 \\
\hline Response 4 & $\begin{array}{l}\text { I did not know how to use } \\
\text { such programs as Zoom, } \\
\text { Skype, etc. }\end{array}$ & 4 & $\mathbf{6 , 9}$ \\
\hline Response 5 & $\begin{array}{l}\text { I could not concentrate in my } \\
\text { room because my roommates } \\
\text { also had online-lessons }\end{array}$ & 17 & $\mathbf{2 9 , 3}$ \\
\hline
\end{tabular}


End of Table 2

\begin{tabular}{l|l|c|c}
\hline № Response & \multicolumn{1}{|c|}{ Response option } & $\begin{array}{c}\text { Number } \\
\text { of respondents } \\
\text { (people.) }\end{array}$ & $\begin{array}{c}\text { Percentage } \\
\text { (\%) }\end{array}$ \\
\hline Response 6 & $\begin{array}{l}\text { I experienced health prob- } \\
\text { lems: strained eyes, backache, } \\
\text { I got tired quickly }\end{array}$ & 15 & 25,9 \\
\hline Response 7 & $\begin{array}{l}\text { Online lessons were boring, } \\
\text { uninteresting and badly } \\
\text { organized in comparison with } \\
\text { classroom lessons. }\end{array}$ & 12 & 20,7 \\
\hline Response 8 & $\begin{array}{l}\text { It was more difficult for } \\
\text { me to communicate with } \\
\text { the teacher online rather than } \\
\text { in class }\end{array}$ & 17 & $\mathbf{2 9 , 3}$ \\
\hline answer 9 & $\begin{array}{l}\text { I did not experience any } \\
\text { difficulties in the process of e- } \\
\text { learning }\end{array}$ & 12 & 20,7 \\
\hline answer 10 & $\begin{array}{l}\text { Others (write your own } \\
\text { answer) }\end{array}$ & 1 & $\begin{array}{l}\text { • "everything } \\
\text { was perfect". }\end{array}$ \\
\hline
\end{tabular}

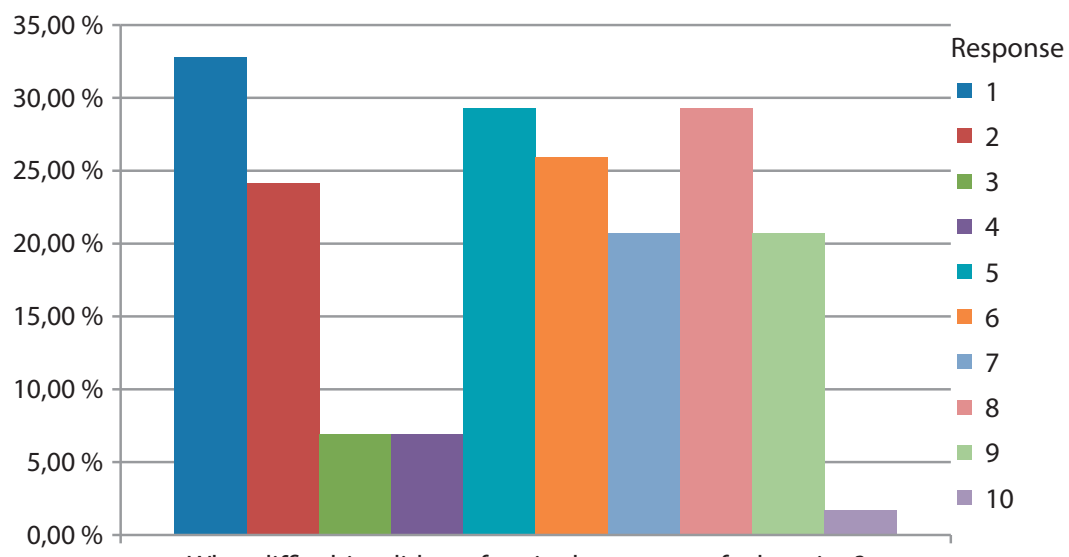

What difficulties did you face in the process of e-learning?

Diagram 2. Difficulties in the process of e-learning 


\section{The results obtained and their interpretation}

More than $40 \%$ of students mentioned that it was difficult for them to study distantly. (Table 1).

As we can see from Table 2 the greatest challenges of e-learning were connected with the quality of the Internet $(32,8 \%)$, uncomfortable conditions of the online lessons $(29,3 \%)$, and also lack of real live communication with teachers and group mates $(29,3 \%)$.

Interestingly, the results of the poll largely overlap the results of national Russian university students polls, carried out by the Institute of Education of the NRU HSE from the $25^{\text {th }}$ of March until the $3^{\text {rd }}$ of April 2020 where 11005 thousand respondents took place. The data obtained was published in the analytical report of the Institute of Education the NRU HSE 'Storm of the first weeks: how has the higher education stepping into the pandemic reality?"

"The most common problems faced by the students are lack of communication with group mates (35\%), various technical challenges and unstable Internet connection (34\%), lack of live discussion with the teachers (34\%). Besides there were other common problems such as: difficulties in concentration while self-studying (29\%), difficulties in studying in the home environment $(28 \%)$, difficulties in asking questions to the teacher $(27 \%)$, feeling lonely and isolated (25\%)" ["Storm of the first weeks: how has the higher education stepping into the pandemic reality?"2020, 67].

In the report 'Lessons of 'stress-test'. Universities in the conditions of pandemic and after it" which has already been mentioned in our article it is stated "more than $40 \%$ of students mention the lack of live communication with a teacher and group mates as the main challenge of e-learning". [Lessons of 'stress-test". Universities in the conditions of pandemic and after it, 2020, 22].

Thus, technical, social and psychological aspects of distant learning in the period of self-isolation were not thought out properly. It is for sure that technical challenges will be sooner or later solved, however questions remain whether it will be possible to shift some social and psychological aspects of university life into an online mode. According to experts and analytics of the Institute of Education of the NRU HSE "a number of the most important processes of university life have difficulties in digitalization and shifting into the virtual environment. In the real life conditions it was proved that complete realization of higher education programs in distant mode is impossible" 


\section{The findings of the research}

This e-learning experience showed that the methodic, computer and distant technologies made it possible to shift classroom studies to e-learning mode. Definitely, the mechanisms are not perfect at the time being, there is a wide-spread opinion that there is no need to shift the education to a distant learning mode. Both teachers and students express this opinion. The authors of this article support the point of view that distant learning cannot totally replace the live teaching and learning process, however as we can see from experience, it can become a helpful supplement in the process of teaching foreigners Russian as a Foreign Language.

The difficulties, which faced both teachers and students, appeared because the shift to distant learning was carried out in the so-called force majeure conditions. Neither teachers nor students were or had to be ready for such a dramatic change to this mode of studies. It is worth mentioning that what we mostly experienced has been an attempt to shift the elements of live lessons to the distant mode and it cannot be considered as full-fledged e-learning. E-learning is a well-thought out, technically and methodically constructed process.

Education export and academic mobility suffered severe losses because of the closed borders. Students who went back home for winter holidays have not come back to Russia yet. As things stand at the end of August, only foreign students of four countries can come to Russia: Turkey, Great Britain, Tanzania, Switzerland and Abkhazia.

Taking into account the importance of the national system of higher education support in the conditions of dramatically changing social and economic situations in the course of the pandemic and also external challenges in organizing enrolling the foreign students into Russian universities in 2020/2021 academic year, and also the necessity to provide the applicants with flexible mechanisms of learning, many educational organizations of higher education began to look into opportunities for distant preparation of foreign applicants to entering Russian universities.

In order to maintain the position of Russian universities in the market of education exports it is crucial to provide the Pre-University Faculties with the necessary infrastructure, platforms and services which will enable conducting education in the distant mode. The same applies to the foreign students who continue their education at the Russian universities but are not able to come to Russia by the beginning of the academic year. 


\subsection{Further perspectives}

From September 2020, several universities announced the launch of distant digital Pre-University courses. Among them, there are Russian University of Peoples' Friendship and Pushkin State Russian Language Institute, Russian University of Peoples' Friendship is actively developing distant education and at the time being, the teaching of foreign students is planned in several ways including the Digital Pre-University Faculty (http://info.langrus.rudn.ru/).

Digital Pre-University Faculty is an international model of teaching foreign citizens in accordance with the programs of Pre-University Faculties of Russian Universities, which is conducted fully or partially using modern distant learning technologies.

The process of education will be organized via a digital platform. Implementation of this project in such a mode will make it possible to make education more flexible for listeners (the length of the basic program varies from 6 months to 2 years, also there is an opportunity to complete separate modules and students can enroll on the program all the year round).

While studying, listeners will be supported by experienced teachers of RUPF and tutors via video consultations, also there will be provided 24 hours support-chat in Russian or an intermediate language.

Basic preparatory course of Digital Pre-University Faculty consists of nine modules:

- Four main modules of Russian Language: Phonetics, Elementary, Basic and the First Certificate Levels.

- Three variable modules in General Subjects. Listeners have an opportunity to choose among 8 subject modules provided - Mathematics, Physics, Chemistry, Biology. History, Social Studies, Literature, IT.

- One module on scientific speech style. Listeners can choose one optional course - Science, Medicine and Biology, Economics, Humanitarian, Engineering and Technology.

- One cultural module. This module is aimed at the social and cultural adaptation of the student who will discover geography and peoples, traditions and holidays of Russia. There is an opportunity to visit virtual excursions of the best museums of the country.

Pushkin State Russian Language Institute has introduced in September 2020 the preparation program of Russian and principal subjects for foreign citizens who want to obtain a degree at Pushkin State Russian Language Institute and other universities of Russia (https://www.pushkin.institute/ education/dop/podfak/). 
The programs meet the "Requirements to minimal contents and standards for graduates of Pre-University Faculties teaching foreign citizens. Foreign citizens and people without citizenship who have received or receiving education in their home countries and want to study Russian language in the remote mode and aim at entering universities of the Russian Federation, have an opportunity to choose from five stream: Humanities, Economics, Medicine and Biology, Natural Science, Engineering and Technology. Listeners can study not only Russian but also various subjects according to their major.

- Humanities: Russian language, Literature, Social Studies, History.

- Economics: Russian language, Mathematics, Chemistry, Physics.

- Natural Science: Russian language, Mathematics, Chemistry, Physics.

- Medicine and Biology: Russian language, Biology, Chemistry, Physics.

- Engineering and Technology: Russian Language, Mathematics, Physics, Educational programs have module structure.

- Module 1. Russian for day-to-day communication from "zero" level to the level B1.

- Module 2. Russian language for education. Studying the language for the chosen major.

- Module 3. Reading subjects in Russian. Studying of the basic subjects necessary for the future degree.

The time span for mastering the program varies from ten months to three years depending on the number of lessons per week. The number of academic hours per week: minimum is four hours of contact work. The total number of hours is 2376 including contact work with teachers and self-study. Also there are provided express-courses, which vary from one to six months. The lessons are conducted in the digital educational environment of the institute, using interactive online courses in Russian as a Foreign language and principal subjects in Russian Language in the system of education based on LMS Canvas on the portal "Education in Russian" (http://pushkininstitute. $\mathrm{ru} /$ ). Contact lessons with teachers are conducted via video conference systems such as Zoom and AdobeConnect. Groups of 15 people are formed to study at the Pre-University Faculty. Distant lessons with the students are conducted by the teachers of Pushkin Institute. Students can attend lessons at a definite time according to their time zones. To make the process of studies in the online environment more effective, students are provided with online curators assistance. Studying at the Pushking Institute enables students to take part in online lectures, cultural events, competitions of the Institute and visit online excursions in Moscow and its museums. 
It is clear that the first semester of the 2020/2021 academic year will become a crash test for the brand new mechanism of teaching foreign students at Pre-University Faculties of Russian Universities. Digital preparatory courses based on the digital educational platforms including both online consultations of teachers of Russian as a Foreign Language and complete learning materials of educational programs will provide the realization of the educational process, however its results will be estimated only after some time.

\section{Conflict of Interest}

The authors have no conflict of interest to declare.

\section{References:}

1. Sajt ministerstva nauki i vysshego obrazovaniya Rossijskoj Federacii [Website of RF Ministry of Science and Higher Education], https://minobrnauki.gov.ru/ru/ press-center/card/?id_4=2328 (Accessed 26 August 2020).

2. Institut obrazovaniya VSHE, analiticheskij doklad «Uroki "stress-testa"». Vuzy v usloviyah pandemii i posle neyo» [Institute of Education of HSE, analytical report "Cases of quick reaction of universities in the period of pandemic"], https://ioe.hse.ru/ mirror/pubs/share/364241595.pdf (Accessed 26 August 2020).

3. Virtual'naya sreda obucheniya russkomu yazyku kak inostrannomu: lingvokul'turologicheskij aspekt [Institute of Education of HSE, analytical report "The lessons of "stresstest". Universities under the conditions of pandemic and after it"], https://www.hse.ru/ data/2020/07/06/1595281277/003_Доклад.pdf (Accessed 26 August 2020).

4. A.N. Bogomolov. Sistema obucheniya vospriyatiyu i ponimaniyu russkoj rechi na materiale informacionno-razvlekatel'nyh programm internet-televideniya (Pervyj sertifikacionnyj uroven') [Virtual environment in teaching Russian as a Foreign Language: linguistic and cultural aspects]. - MAKS Press, Moscow (2008).

5. I.I. Prokopova. Sistema obucheniya vospriyatiyu i ponimaniyu russkoj rechi na materiale informacionno-razvlekatel'nyh programm internet-televideniya (Pervyj sertifikacionnyj uroven') [System of teaching of Russian speech perception and understanding based on informative and entertainment programs of internet television (First certificate level)]. Dissertation... Candidate of Pedagogic Science. Moscow (2019).

6. Zakony, kodeksy i normativno-pravovye akty Rossijskoj Federacii [Laws, codes and regulations of the Russian Federation], https://legalacts.ru/doc/273_FZ-ob-obrazovanii/glava-2/statja-16/ (Accessed 26 August 2020).

7. Institut obrazovaniya VSHE, analiticheskij doklad «Shtorm pervyh nedel’: kak vysshee obrazovanie shagnulo v real'nost' pandemii?» [Institute of Education NRU 
HSE analytical report "The storm of the first weeks: has has the higher education stepped into pandemic reality"], https://ioe.hse.ru/data/2020/05/26/1551527214/ CAO 6(36)_электронный.pdf (Accessed 26 August 2020).

DOI 10.15826/B978-5-7996-3081-2.07

\title{
New Communicative and Expressive Powers in Online and Offline Teaching Russian as a Foreign Language
}

\author{
Martynova Margarita ${ }^{1}$, Nikolenko Elena ${ }^{2}$, Nikolenko Galina ${ }^{3}$ \\ ${ }^{1}$ Moscow State University of Geodezy and Cartography; Plekhanov Russian \\ University of Economics, Moscow, Russia \\ ${ }^{2}$ Moscow State University, Moscow, Russia \\ ${ }^{3}$ Moscow State University, Moscow, Russia \\ Corresponding author: Martynova Margarita, bilingualconnect@mail.ru
}

\begin{abstract}
The article contains the first results of online education of foreign students with various levels of competence in the Russian language (mainly in conditions of the Russian educational environment). On the example of teaching non-native learners with a philological and non-philological focus in a new distant working mode caused by the pandemic, the defined pros and cons of education in a new educational reality are analyzed. Communicative and expressive powers of online and offline education in teaching Russian as a foreign language are viewed in this context.
\end{abstract}

Keywords: on-line teaching, off-line teaching, Russian as a Foreign Language (RFL), on-line communication, social networks

\section{Introduction}

Unfortunately, today we cannot say that the danger of the pandemic has fully passed. But its first wave put all of us regardless countries and continents into unusual conditions of life and activity. According to research data, 400 million students of colleges and universities all over the world moved to a new mode of education [T4 Education]. Specialists in various fields of knowledge agree that the world will not be the same again. Professionals 